
УДК 616.8-089

DOI 10.11603/1811-2471.2021.v.i2.12221

\title{
ОЦІНКА ВПЛИВУ ІМУНОТРОПНОГО ЗАСОБУ НА СТАН КЛІТИННОГО ІМУНІТЕТУ ХВОРИХ ІЗ ЧЕРЕПНО-МОЗКОВОЮ ТРАВМОЮ НА АМБУЛАТОРНОМУ ЕТАПІ ЛІКУВАННЯ
}

\author{
๑Ю. Ю. Шаповалова, С. А. Усатов \\ ДЗ «Луганський державний медичний університет»
}

PЕЗЮМЕ. Одним із найтяжчих видів травматизму на сучасному етапі $є$ черепно-мозкова травма (ЧМТ). Вона часто призводить до фатальних наслідків, ускладнюється травматичною хворобою мозку, яка має хронічний і, нерідко, прогредієнтний перебіг. Стан імунної системи на сьогодні розглядають як визначальний у механізмах хронізації та ушкодження морфології і основних функцій головного мозку постраждалих.

Мета дослідження - вивчити показники клітинного імунітету у постраждалих від ЧМТ середньої тяжкості під час амбулаторного спостереження під впливом нуклеїнату.

Матеріал і методи. Обстежено 57 пацієнтів, які перенесли ЧМТ середньої тяжкості - забій головного мозку середньої тяжкості після оперативного втручання з приводу гематоми або вдавленого перелому кісток черепа, які перебували під амбулаторним спостереженням. У пацієнтів досліджували стан клітинного імунітету із застосуванням тесту з моноклональними антитілами класів CD3+, CD4+, CD8+ і CD22+ (НВЦ «МедБиоСпектр», Москва, PФ) у цитотоксичному тесті перед виписуванням та після одного місяця амбулаторного нагляду.

Результати. Всі хворі, що перенесли ЧМТ, які були під наглядом невролога на амбулаторному етапі, мали, за даними імунологічного дослідження, ознаки вторинного імунодефіциту. Через 1 місяць після виписування зі стаціонару на тлі тритижневого лікування із доповненням нуклеїнатом визначено суттєве поліпшення всіх показників клітинного імунітету. Додавання нуклеїнату до традиційних нейропротекторних засобів на амбулаторному етапі відобразилося на динаміці імунорегуляторного індексу CD4/CD8, який в основній групі став вищим, ніж у групі порівняння, на 29,8 \% (р<0,05). Значення CD22+-лімфоцитів не змінювалися впродовж періоду спостереження.

Висновки. При додаванні препарату «Нуклеїнат» на амбулаторному етапі спостереження в осіб із перенесеною ЧМТ відбувалося суттєвіше, ніж у групі порівняння, зростання загальної популяції Т-лімфоцитів, підвищення вмісту CD4+-клітин та зростання показника CD4/CD8. Часткове відновлення показників клітинного імунітету відбулося у 31 пацієнта (54,4\%).

КЛючОВІ СлОВА: нуклеїнат; черепно-мозкова травма; показники клітинного імунітету; амбулаторний етап.

Вступ. Одним із найтяжчих видів травматизму на сучасному етапі $є$ черепно-мозкова травма (ЧМТ). Вона часто призводить до фатальних наслідків, ускладнюється травматичною хворобою мозку, яка має хронічний і, нерідко, прогредієнтний перебіг $[1,2]$. Стан імунної системи сьогодні розглядають як визначальний у механізмах хронізації та ушкодження морфології і основних функцій головного мозку постраждалих $[3,4]$.

Очевидним $\epsilon$ факт вторинного імунодефіциту за рахунок змін у показниках клітинного імунітету хворих після перенесеної ЧМТ. Ослаблення клітинної ланки імунітету може передувати або збігатися із процесами гальмування його гуморальної ланки, що призводить до високого рівня нейросенсибілізації та автоімунних реакцій [4-6]. Вторинний імунодефіцит зберігається довго - роками після перенесеної ЧМТ [7], коли хворий продовжує лікуватись під наглядом невролога. Ось чому вивчення стану показників клітинного імунітету при ЧМТ у реабілітаційному періоді та можливість корекції імунних показників залишаються недостатньо з'ясованими і потребують вивчення.

Значна роль на амбулаторному етапі, поряд із нейропротекцією, належить імунореабілітації. Для останньої був запропонований імуноактивний препарат «Нуклеїнат», який $є$ похідним дріж- джової рибонуклеїнової кислоти. Нуклеїнові кислоти мають імуностимулювальні та репаративні властивості, стимулюють синтез імуноглобулінів. За спостереженнями, під впливом нуклеїнату відбувається усунення дисбалансу популяцій лімфоцитів [8], що є важливим для корекції клітинного імунітету. Інструкція з клінічного застосування нуклеїнату затверджена наказом MO3 України № 197 від 16.03.2016 р. (реєстраційне свідоцтво препарату № UA/2885/01/02). Оптимальною дозою для дорослих $\epsilon$ 1,5 г препарату на добу (по 2 капсули 3 рази на день після їди) впродовж 2 тижнів поспіль, але в деяких клінічних випадках термін лікування може бути продовженим [8]. Препарат підвищує активність неспецифічного імунного захисту, активує полі- та мононуклеари, збільшує ефективність антибактеріальних препаратів, підвищує продукцію ендогенного інтерферону та стимулює противірусний захист.

Мета - вивчити показники клітинного імунітету у постраждалих від ЧМТ середньої тяжкості під впливом лікування нуклеїнатом під час амбулаторного спостереження.

Матеріал і методи дослідження. Обстежували 57 осіб, які перенесли ЧМТ середньої тяжкості - забій головного мозку середньої тяжкості після оперативного втручання з приводу гемато- 
Огляди літератури, оригінальні дослідження, погляд на проблему, випадок з практики, короткі повідомлення ми або вдавленого перелому кісток черепа, які перебували під амбулаторним спостереженням.

У пацієнтів досліджували стан клітинного імунітету із застосуванням тесту з моноклональними антитілами класів CD3+, CD4+, CD8+ и CD22+ (НВЦ «МедБиоСпектр», Москва, РФ) у цитотоксичному тесті за методикою В. М. Фролова (1989) [9] перед виписуванням та після одного місяця амбулаторного нагляду. Хворим основної групи (30 осіб), поряд із загальноприйнятими засобами нейропротекції, призначали нуклеїнат у дозі 1 капсула (0,25 г) 4 рази на добу після їди впродовж 3 тижнів. Групу порівняння склали 27 травмованих, які нуклеїнат не отримували. Серед обстежених було 53 чоловіки та 4 жінки. Середній вік обстежених становив $(34,3 \pm 3,8)$ роки.

Для розробки референтної норми було обстежено 21 практично здорову особу в такому ж віковому та гендерному діапазонах.

Результати й обговорення. Всі хворі, які перенесли ЧМТ, що перебували під наглядом нев-

ролога на амбулаторному етапі, за даними імунологічного дослідження мали ознаки вторинного імунодефіциту. Через 1 місяць після виписування зі стаціонару на тлі тритижневого проведення лікування із доповненням нуклеїнатом відзначено суттєве поліпшення всіх показників клітинного імунітету.

Показник CD3+-лімфоцитів при обчисленні в абсолютних цифрах у пацієнтів основної групи підвищився до $(1,19 \pm 0,03) \times 10^{9} / л$, і перевищував аналогічний у групі порівняння у 1,12 раза (табл. 1). У пацієнтів групи порівняння вміст CD3+клітин підвищився на 3,92 \% від вихідного. Водночас зростання показника загальної популяції Т-лімфоцитів у пацієнтів основної групи було інтенсивнішим - у 1,35 раза або на 5,3 \% від початкового. У відносних числах значення CD3+лімфоцитів у осіб основної групи були незначно вищими за такі у хворих групи порівняння та на 9,04 \% нижчими за аналогічні у практично здорових осіб.

Таблиця 1. Динаміка показників клітинного імунітету у хворих на ЧМТ середньої тяжкості при лікуванні нуклеїнатом на амбулаторному етапі спостереження

\begin{tabular}{|c|c|c|c|c|c|}
\hline \multirow[b]{2}{*}{ Показник } & \multirow{2}{*}{$\begin{array}{c}\text { Показник } \\
\text { здорових осіб } \\
(n=21) \\
\end{array}$} & \multicolumn{2}{|c|}{ Група порівняння (n=27) } & \multicolumn{2}{|c|}{ Основна група (n=30) } \\
\hline & & $\begin{array}{c}\text { після } \\
\text { виписування }\end{array}$ & $\begin{array}{c}\text { через } \\
1 \text { місяць нагляду }\end{array}$ & $\begin{array}{c}\text { після } \\
\text { виписування }\end{array}$ & $\begin{array}{c}\text { через } \\
1 \text { місяць нагляду }\end{array}$ \\
\hline $\begin{array}{l}\text { CD3+: } \\
\text { число кл. } \times 10^{9} / л, \\
\%\end{array}$ & $\begin{array}{c}1,26 \pm 0,04 \\
68,30 \pm 2,46\end{array}$ & $\begin{array}{l}1,02 \pm 0,03^{*} \\
55,23 \pm 1,9^{*}\end{array}$ & $\begin{array}{c}1,06 \pm 0,05^{*} \\
57,31 \pm 1,71^{*}\end{array}$ & $\begin{array}{l}1,13 \pm 0,03 * \\
61,20 \pm 2,17\end{array}$ & $\begin{array}{l}1,19 \pm 0,03) \\
62,40 \pm 3,12\end{array}$ \\
\hline $\begin{array}{l}\text { CD4+: } \\
\text { число кл. } \times 10^{9} / л, \\
\%\end{array}$ & $\begin{array}{c}0,84 \pm 0,03 \\
45,53 \pm 1,60\end{array}$ & $\begin{array}{c}0,56 \pm 0,04^{*} \\
30,32 \pm 1,86^{*}\end{array}$ & $\begin{array}{c}0,62 \pm 0,06 * \\
33,52 \pm 1,28 *)\end{array}$ & $\begin{array}{c}0,72 \pm 0,04 * \\
38,99 \pm 1,48 *\end{array}$ & $\begin{array}{c}0,77 \pm 0,03 *) \\
40,38 \pm 1,20 *\end{array}$ \\
\hline $\begin{array}{l}\text { CD8+: } \\
\text { число кл. } \times 10^{9} / л, \\
\%\end{array}$ & $\begin{array}{c}0,42 \pm 0,02 \\
22,77 \pm 0,79\end{array}$ & $\begin{array}{c}0,46 \pm 0,02 \\
24,93 \pm 2,25\end{array}$ & $\begin{array}{l}0,44 \pm 0,04 * \\
23,79 \pm 1,90\end{array}$ & $\begin{array}{c}0,41 \pm 0,03 \\
22,21 \pm 1,85\end{array}$ & $\begin{array}{c}0,42 \pm 0,05 \\
22,02 \pm 1,45\end{array}$ \\
\hline CD4/CD8 & $2,00 \pm 0,05$ & $1,22 \pm 0,04 *$ & $1,41 \pm 0,04 *$ & $1,76 \pm 0,04 *$ & $1,83 \pm 0,06 *)$ \\
\hline $\begin{array}{l}\text { CD22+: } \\
\text { число кл. } \times 10^{9} / л, \\
\%\end{array}$ & $\begin{array}{c}0,44 \pm 0,01 \\
21,60 \pm 0,80 \\
\end{array}$ & $\begin{array}{l}0,47 \pm 0,07 \\
23,1 \pm 1,45 \\
\end{array}$ & $\begin{array}{l}0,47 \pm 0,07 \\
23,1 \pm 1,45 \\
\end{array}$ & $\begin{array}{l}0,48 \pm 0,04 \\
21,9 \pm 0,90 \\
\end{array}$ & $\begin{array}{l}0,45 \pm 0,03 \\
21,7 \pm 0,60 \\
\end{array}$ \\
\hline
\end{tabular}

Примітки:

1. * - p<0,05 при порівнянні із практично здоровими особами;

2. ) - p<0,05 при порівнянні показників між групами

Вміст CD4+-лімфоцитів у пацієнтів основної групи зростав менш інтенсивно, ніж у групі порівняння, i досяг в абсолютному обчисленні $(0,77 \pm 0,03) \times 10^{9} / л$ та став достовірно вищим, ніж у групі порівняння, у 1,2 раза $(p<0,05)$.

Пул CD8+-клітин в основній групі не зазнавав суттєвої динаміки і становив в абсолютному вирахуванні $(0,42 \pm 0,05) \times 10^{9} / л$, а у відносному $(21,87 \pm 1,45) \%$. Динаміка вмісту CD8+-лімфоцитів у групі порівняння була аналогічною.

Додавання нуклеїнату до традиційних нейропротекторних засобів на амбулаторному етапі відобразилося на динаміці імунорегуляторного ін- дексу CD4/CD8, який в основній групі досяг $(1,83 \pm 0,06)$ у. о., і став вищим, ніж у групі порівняння, на $29,8 \%(p<0,05)$.

Значення CD22+-лімфоцитів не змінювалися протягом періоду спостереження, що, вочевидь, пояснюється неалергічним характером патологічного процесу.

Висновки. При додаванні нуклеїнату на амбулаторному етапі спостереження осіб із перенесеною ЧМТ відзначалося більш суттєве, ніж в групі порівняння, зростання загальної популяції Т-лімфоцитів, підвищення вмісту CD4+-клітин та зростання показника CD4/CD8, що було отримано і в 
Огляди літератури, оригінальні дослідження, погляд на проблему, випадок з практики, короткі повідомлення

інших дослідженнях дії нуклеїнату $[5,8]$. Часткове відновлення показників клітинного імунітету відбулося у 31 пацієнта (54,4\%).

\section{ЛІТЕРАТУРА}

1. Prognostic value of demographic characteristics in traumatic brain injury: results from the IMPACT study / N. A. Mushkudiani, D. C. Engel, E. W. Steyerberg [et al.] // J. Neurotrauma. - 2007. - Vol. 24 (2). - P. 259-269.

2. Faul M. Epidemiology of traumatic brain injury / M. Faul, V. Coronado // Handbook of Clin Neurol. - 2015. Vol. 127. - P. 3-13.

3. Depressed interleukin-12-producing activity by monocytes with ad-verse clinical course and a shift toward Th2 type lymphocyte pattern in severely injured male trauma patients / Z. Spolarics, M. Sid-diqi., J. N. H. Siegel [et al.] // Crit. Care Med. - 2003. - Vol. 3 (6). - P. 1722-1729.

4. Особливості порушень імунної системи при експериментальній легкій черепно-мозковій травмі у щурів / М.І. Лісяний, Л. М. Бєльська, А. В. Паламарьова, А. Г. Потапова // Імунологія та алергологія: наука і практика. - 2020. - № 1. - С. 58-63.

5. Дранник Г. Н. Клиническая иммунология и ал-

\section{REFERENCES}

1. Mushkudiani, N.A., Engel, D.C., Steyerberg, E.W., Butcher, I., Lu, J., Marmarou, A., \& Maas, A.I.R. (2007). Prognostic value of demographic characteristics in traumatic brain injury: results from the IMPACT study. J. Neurotrauma, 24 (2), 259-269. DOI:10.1089/neu.2006.0028

2. Faul, M. \& Coronado, V. (2013). Epidemiology of traumatic brain injury. Handbook of Clin. Neurol., 127, 3-13.

3. Spolarics, Z., Siddiqi, M., Siegel, J.N.H., Garcia, Z.C., Stein, D.S., Denny T., et al. (2003). Depressed interleukin-12 - producing activity by monocytes with adverse clinical course and a shift toward Th2 type lymphocyte pattern in severely injured male trauma patients. Crit. Care Med., 6 (3), 1722-1729. DOI: 10.1097/01.CCM.0000063579.43470.AA

4. Lisianyi, M.I., Bielska, L.M., Palamarova, A.V., \& Potapova, A.H. (2020) Osoblyvosti porushen imunnoi systemy pry eksperymentalnii lehkii cherepno-mozkovii travmi u shchuriv [Features of disorders of the immune system in experimental mild traumatic brain injury in rats]. Imunolohiia ta alerholohiia: nauka i praktyka - Immunology and Allergology: Science and Practice, 1, 58-63 [in Ukrainian]. DOI:10.37321/immunology.2020.01-08
Перспективи подальших досліджень. Подальші дослідження спрямовані на спостереження імунного статусу хворих у віддалені терміни відновлювального періоду після перенесеної черепно-мозкової травми.

лергология / Г. Н. Дранник. - М. : Медицинское информационное агенство, 2003. -603 c.

6. Humoral and cellular immunity changed after traumatic brain injury in human patients / J. W. Wang, J. P. Li, Y. L. Song [et al.] // Ann. Clin. Lab. Sci. - 2017. - Vol. 47 (1). P. 10-16.

7. Jimenez L. Lee. Traumatic brain injury and stroke / L. Lee Jimenez, F. Davis // Nutrition Support for the Critically III Patient: A Guide to Practice. - 2004. - Vol. 32. - P. 529-540.

8. Прилуцкий А. С. Применение нуклеината в комплексной терапии рецидивирующей герпетической инфекции / А. С. Прилуцкий, А. С. Сергиенко, Д. А. Лесниченко // Новости медицины и фармации. - 2008. № 256. - С. 19-21.

9. Моноклональные антитела в изучении показателей клеточного иммунитета у больных рожей / В. М. Фролов, И. С. Гайдаш, Н. А. Пересадин [и др.] // Лабораторное дело. - 1989. - № 6. - С. 71-72.

5. Drannik, G.N. (2003). Klinicheskaya immunologiya $i$ allergologiya [Clinical immunology and allergology]. Moscow: Medicinskoe informacionnoe agenstvo. [in Russian].

6. Wang, J.W., Li, J.P., Song, Y.L., \& Zhao, Q.H. (2017). Humoral and cellular immunity changed after traumatic brain injury in human patients. Ann. Clin. Lab. Sci., 47 (1), 10-16.

7. Jimenez, L. Lee, \& Davis, F. (2004). Traumatic brain injury and stroke. Nutrition Support for the Critically III Patient: a Guide to Practice, 32, 529-540.

8. Priluckij A.S., Sergienko A.S., \& Lesnichenko D.A. (2008). Primenenie nukleinata $v$ kompleksnoj terapii recidiviruyushchej gerpeticheskoj infekcii [The use of nucleinate in the complex therapy of recurrent herpes infection]. Novosti mediciny i farmacii - News of Medicine and Pharmacy, 256, 19-21 [in Russian].

9. Frolov, V.M., Gajdash, I.S. \& Peresadin, N.A. (1989). Monoklonalnye antitela $v$ izuchenii pokazatelej kletochnogo immuniteta u bolnyh rozhej [Monoclonal antibodies in the study of parameters of cellular immunity in patients with erysipelas]. Laboratornoe delo - Laboratory Work, 6, 71-72 [in Russian]. 


\title{
Огляди літератури, оригінальні дослідження, погляд на проблему, випадок з практики, короткі повідомлення ОЦЕНКА ВЛИЯНИЯ ИММУНОТРОПНОГО ПРЕПАРАТА НА СОСТОЯНИЕ КЛЕТОЧНОГО ИММУНИТЕТА БОЛЬНЫХ С ЧЕРЕПНО-МОЗГОВОЙ ТРАВМОЙ НА АМБУЛАТОРНОМ ЭТАПЕ ЛЕЧЕНИЯ
}

๑Ю. Ю. Шаповалова, С. А. Усатов

\author{
ГУ «Луганский государственный медицинский университет»
}

РЕЗЮМЕ. Одним из самых тяжелых видов травматизма на современном этапе является черепно-мозговая травма (ЧМТ). Она часто приводит к фатальным последствиям, осложняется травматической болезнью мозга, имеет хроническое и, нередко, прогредиентное течение. Состояние иммунной системы в настоящее время рассматривается как определяющее в механизмах хронизации и повреждения морфологии и основных функций головного мозга пострадавших.

Цель - изучить показатели клеточного иммунитета у пострадавших от чМТ средней тяжести во время амбулаторного наблюдения под влиянием нуклеината.

Материалы и методы. Исследованию подлежали 57 пациентов с перенесенной ЧМТ средней тяжести ушибом головного мозга средней тяжести после оперативного вмешательства по поводу гематомы или вдавленного перелома костей черепа, которые наблюдались амбулаторно. У пациентов исследовалось состояние клеточного иммунитета с применением теста с моноклональными антителами классов CD3+, CD4+, CD8+ и CD22+ (НВЦ «МедБиоСпектр», Москва, РФ) в цитотоксическом тесте перед выпиской и после одного месяца амбулаторного наблюдения.

Результаты исследования. Все больные с перенесенной ЧМТ, поступивши под надзор невролога на амбулаторном этапе, имели, по данным иммунологического исследования, признаки вторичного иммунодефицита. Через 1 месяц после выписки из стационара на фоне трехнедельного проведения лечения с добавлением нуклеината отмечено существенное улучшение всех показателей клеточного иммунитета. Добавление нуклеината к традиционным нейропротекторным средств на амбулаторном этапе отразилось на динамике иммунорегуляторного индекса CD4/CD8, который в основной группе стал выше, чем в группе сравнения, на 29,8 \% $(p<0,05)$. 3начение CD22 + лимфоцитов не менялись в течение периода наблюдения.

Выводы. При добавлении препарата нуклеинат на амбулаторном этапе наблюдения пациентов с перенесенной ЧМТ отмечался более существенный, чем в группе сравнения, рост общей популяции Т-лимфоцитов, повышение содержания CD4+ клеток и рост показателя CD4/CD8. Частичное восстановление показателей клеточного иммунитета произошло у 31 пациента (54,4\%).

КЛЮчЕВЫЕ СЛОВА: нуклеинат; черепно-мозговая травма; показатели клеточного иммунитета; амбулаторный этап.

\section{EVALUATION OF INFLUENCE OF IMMUNE DRUG ON CELL IMMUNITY OF THE PATIENTS AFTER TRAUMATIC BRAIN INJURY ON STAGE OF OUTPATIENT TREATMENT}

\author{
๑Yu. Yu. Shapovalova, S. A. Usatov

\section{SI «Luhansk State Medical University»}

SUMMARY. One of the most serious injuries at the present stage is traumatic brain injury (TBI). It often leads to fatal consequences, complicated by traumatic brain disease, which has a chronic and often progressive course. The state of the present immune system is considered to be decisive in the mechanisms of chronicity and damage to the morphology and basic functions of the brain of the victims.

The aim - to study the indicators of cellular immunity in patients with moderate trauma during outpatient observation under the influence of nucleinate.

Material and Methods. The study included 57 patients with moderate traumatic brain injury - moderate brain contusion after surgery for hematoma or depressed fracture of the skull, which were observed on an outpatient basis. Patients were examined for cellular immunity using a test with monoclonal antibodies of classes CD3+, CD4+, CD8+ and CD22 + (NPC "MedBioSpectrum", Moscow, Russia) in a cytotoxic test before discharge and after one month of outpatient supervision.

Results. All patients with TBI who came to the supervision of a neurologist at the outpatient stage, according to the immunological study had signs of secondary immunodeficiency. One month after discharge from the hospital on the background of three weeks of treatment with the addition of nucleinate, there was a significant improvement in all indicators of cellular immunity. The addition of nucleinate to traditional neuroprotective agents at the outpatient stage affected the dynamics of the immunoregulatory index CD4/CD8, which in the main group became higher than in the comparison group by $29.8 \%(p<0,05)$. The values of CD22 + lymphocytes did not change during the observation period.

Conclusions. When adding the drug nucleinate in the outpatient phase of observation of persons with trauma, there was a more significant than in the comparison group, an increase in the total population of T lymphocytes, an increase in CD4 + cells and an increase in CD4 / CD8. Partial recovery of cellular immunity occurred in 31 patients (54.4\%).

KEY WORDS: nucleinatum; traumatic brain injury; cell immunity; outpatient conditions. 